CZASOPISMO INŻYNIERII LA¿DOWEJ, ŚRODOWISKA I ARCHITEKTURY JOURNAL OF CIVIL ENGINEERING, ENVIRONMENT AND ARCHITECTURE

JCEEA, t. XXXIV, z. 64 (4/I/17), październik-grudzień 2017, s. 435-447, DOI:10.7862/rb.2017.225

\author{
Marian PONIEWIERA ${ }^{1}$ \\ Ewa MACIEJOWSKA-FIGIEL ${ }^{2}$ \\ Justyna ORWAT ${ }^{3}$
}

\title{
ZASTOSOWANIE PROGRAMU GEOLISP DO TWORZENIA DOKUMENTACJI KARTOGRAFICZNEJ ODKRYWKOWEGO ZAKŁADU GÓRNICZEGO
}

\begin{abstract}
W artykule przybliżono system obsługi kopalnianych map numerycznych Geolisp ze szczególnym uwzględnieniem modułu Odkrywki. Omówiono kolejne funkcje modułu i możliwość jego zastosowania przy tworzeniu dokumentacji kartograficznej w górnictwie odkrywkowym. W pierwszej części pokazane zostały sposoby tworzenia map górniczych na podstawie danych z pomiaru. Wyróżnione tu zostały metody wstawiania znaków umownych, linii oraz kreskowań niezbędnych przy tworzeniu tego typu dokumentacji. Następnie przedstawiono możliwości programu przy przetwarzaniu utworzonych map, między innymi: transformacja map między układami współrzędnych, przygotowanie rysunków do wydruku oraz tworzenie map pochodnych. W artykule omówiono istotne, z punktu widzenia górnictwa odkrywkowego, funkcje programu, a mianowicie: obliczanie objętości zwałowisk, tworzenie wykresów (przekroi i profili) oraz powierzchni NMT na podstawie utworzonych map wyrobisk górniczych. Powierzchnie te utworzyć można zarówno na podstawie warstwic jak i wykorzystując współrzędne stropu lub spągu pokładu $\mathrm{np}$. zestawione $\mathrm{w}$ plikach tekstowych. Tak utworzone powierzchnie umożliwiają wizualizację elementów pokładu oraz zaplanowanie dalszych prac górniczych. Kolejno ukazano, jak na bazie utworzonej topologii wykonać mapę tematyczną. W tej części artykułu zostały pokazane kolejne kroki tworzenia parcel oraz kontrola ich topologii, a także sposób wygenerowania raportu parcel. Zaprezentowano także moduł, który służy do przygotowania produkcji. W końcowej części artykułu skupiono się na praktycznych przykładach wykorzystania tak utworzonej dokumentacji kartograficznej.
\end{abstract}

Słowa kluczowe: górnictwo odkrywkowe, mapy numeryczne, mapy górnicze, numeryczny model złoża, obliczanie objętości

\footnotetext{
${ }^{1}$ Autor do korespondencji / corresponding author: Marian Poniewiera, Politechnika Śląska, Wydział Górnictwa i Geologii, Zakład Geodezji i Ochrony Terenów Górniczych, ul. Akademicka 2, 44-100 Gliwice; tel. 322372990; marian.poniewiera@polsl.pl

2 Ewa Maciejowska-Figiel, Politechnika Śląska; ewa.maciejowska-figiel@polsl.pl

3 Justyna Orwat, Politechnika Śląska; justyna.orwat@polsl.pl
} 


\section{Wprowadzenie}

Gdy mówi się o polskim górnictwie, pierwszymi obrazami, jakie stają przed oczami, są: podziemny zakład górniczy, węgiel kamienny i sylwetka pracującego górnika. Jednak to nie górnictwo podziemne, a odkrywkowe stanowi istotną część polskiej gospodarki. Dowodem na to są liczby czynnych kopalni węgla kamiennego jest około 30 (stan na 2016 rok), a tych wydobywających metodą odkrywkową około 7000. Kopalnie te wydobywają 40 różnych kopalin, m.in. surowce energetyczne, kruszywa naturalne (piaski, żwiry) i ilaste (gliny). Roczne wydobycie metodą odkrywkową wynosi ponad $350 \mathrm{mln}$ ton. Zatrudnienie w tego typu kopalniach znajduje tysiące pracowników, i to zarówno jako zaplecze techniczne, jak i badawczo-projektowe [1,2].

Zgodnie z przepisami [3] wszystkie, nawet niewielkie kopalnie muszą sporządzać dokumentację kartograficzną. W dobie komputerów i nowoczesnych technologii tworzenie wymaganej dokumentacji technicznej nie wymaga już dużego nakładu czasu, łatwiejsze jest też dokonywanie coraz bardziej skomplikowanych obliczeń. Pomiary metodami: GPS, fotogrametrycznymi, skaningu laserowego (przy zastosowaniu samolotów lub dronów) dostarczają bardzo dużo szczegółowych informacji o ukształtowaniu terenu. Uporządkowanie tych danych jest możliwe dzięki prowadzeniu map numerycznych, które można powielać, edytować oraz przetwarzać. Stwarza to coraz większe możliwości w zakresie modelowania powierzchni terenu (modele numeryczne) oraz wykonywania tak istotnych w górnictwie odkrywkowym obliczeń, jakimi są szacowanie objętości zwałowisk oraz skarp. Oczywiście, aby wykonywać wszelkie operacje na komputerze, niezbędnym jest posiadanie odpowiedniego oprogramowania przeznaczonego do tego celu. Najlepszym będzie takie, które posiada funkcje umożliwiające pracę z dokumentacją kartograficzną.

Z myślą o tych wymaganiach powstał moduł Odkrywki systemu Geolisp. Sam system zawiera szereg programów wspomagających pracę działu mierniczo-geologicznego (w przypadku zakładów górniczych) oraz samego geodety (w przypadku prac prowadzonych przez niego na powierzchni terenu). Są one pomocne przy tworzeniu, aktualizacji oraz analizie map numerycznych. $\mathrm{Na}$ szczególne wyróżnienie zasługują tu: możliwość uzyskania wybranej mapy tematycznej w dowolnej skali, tworzenie numerycznego modelu terenu wraz z procedurami ułatwiającymi jego wizualizację, obliczanie objętości i tworzenie (interpolacja) warstwic terenu; sporządzanie profili i przekrojów terenu; szybkie kartowanie numeryczne (dostępna pełna biblioteka znaków umownych, zarówno powierzchniowych, jak i górniczych) oraz przeprowadzanie transformacji między układami współrzędnych. System Geolisp zawiera ponad 1000 procedur, które uzupełniają możliwości programu AutoCAD oraz pomagają rozwiązywać konkretne zadania. System ten został podzielony na moduły, a każdy z nich składa się z grupy programów. Programy te zostały ze sobą powiązane tematycznie [4]. 
Można tu jeszcze wspomnieć, że na stronie internetowej www.geolisp.pl dostępny jest darmowy moduł MP-NMT, który zawiera wiele $\mathrm{z}$ opisanych w artykule funkcji.

Opisywany w tym artykule moduł Odkrywki zawiera szereg programów przewidzianych do tworzenia dokumentacji kartograficznej oraz wykonywania, na jej podstawie, obliczeń w zakładach odkrywkowych. Wyróżnić tu można m. in. tworzenie map na podstawie wyników pomiarów bezpośrednich, tworzenie map pochodnych, przetwarzanie map (zmiana skali, transformacja między układami współrzędnych), tworzenie map warstwicowych, profili oraz przekroi. We współpracy z firmą AlgoRes-Soft stworzono moduł służący do kalibracji rastrów.

\section{Tworzenie map na podstawie bezpośredniego pomiaru}

System Geolisp wyposażony jest w szereg przydatnych pasków narzędzi. Paski te można dostosowywać do własnych potrzeb włączając lub wyłączając poszczególne moduły. Na paskach tych umieszczone zostały najczęściej używane linie oraz bloki. Paski, które służą do tworzenia map na podstawie danych bezpośrednio pomierzonych $\mathrm{w}$ terenie, przedstawiono na rysunku 1 .

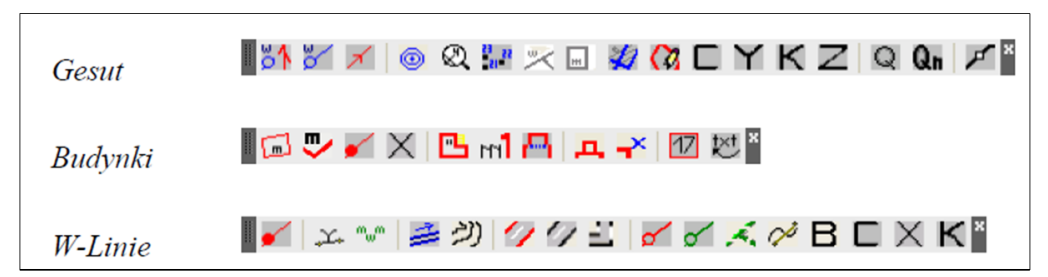

Rys. 1. Paski narzędzi programu Geolisp

Fig. 1. Geolisp toolbars

Większość użytecznych poleceń można wywołać z okna dialogowego MP-Odkrywki (rys. 2), które wywołuje się poleceniem MPO.

\begin{tabular}{|ll|}
\hline punkty & punkty z atrybutów bloku - opAtr \\
wykresy i przekroje & wykres z opcjami - WYKRES \\
objętość i warstwice & menu modelowania Civil - MPM \\
teksty & z okienka wybieram teksty - UL \\
ramka układ skala & menu kalibracji rastra - MP-KAL \\
znaki umowne punkty & znak punktowy uzbrojenia - WOP \\
znaki umowne linie & skarpy odkrywek - sko \\
\hline
\end{tabular}

Rys. 2. Okno dialogowe „MP-ODKRYWKI”

Fig. 2. Dialog box 'MP-OUTCROPS' 
Istotne, z punktu widzenia pracy z programem, jest również ustawienie odpowiednich parametrów początkowych rysunku. W wywołanym oknie MP Ustawienia można wybrać operatora, numer dokumentacji, obiekt, skalę, układ współrzędnych itd.

W skład systemu Geolisp wchodzi bogata biblioteka znaków umownych zawierająca znaki z zakresu geodezji, górnictwa podziemnego i odkrywkowego, geologii, transportu kolejowego, urbanistyki i innych. Podczas kartowania mapy poleceniem WL można wybrać bibliotekę obiektów liniowych, natomiast poleceniem WB bibliotekę obiektów punktowych. Program został wyposażony we wszystkie znaki umowne dotyczące kopalń odkrywkowych, które zostały stworzone na podstawie aktualnie obowiązujących norm [5 - 7]. Skomplikowane znaki umowne kreślone są przy pomocy odpowiednich mini-programów np. nanoszenie skarp odkrywek (rys. 3b). Polecenie SKO otwiera okno dialogowe przedstawione na rysunku $3 \mathrm{a}$.

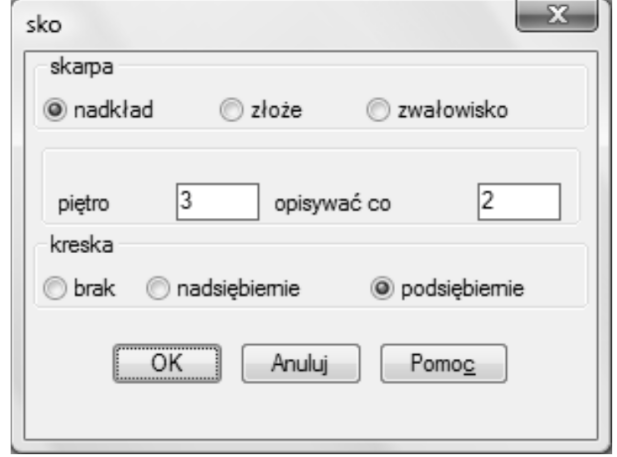

Rys. 3a. Okno dialogowe „SKO”

Fig. 3a. Dialog box 'SKO'

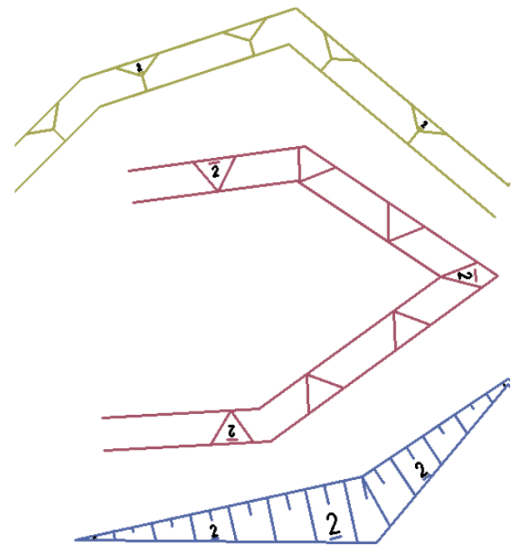

Rys. 3b. Przykład skarpy utworzonej w programie Geolisp

Fig. 3b. Example of a bank made in the Geolisp program

Należy wybrać odpowiednie opcje: czy jest to nadkład, złoże czy zwałowisko, podać, które to piętro, wskazać jak często powinien być posadowiony opis, zaznaczyć odpowiedni typ kreskowania.

\section{Przetwarzanie utworzonych map}

Niewątpliwą przewagą mapy numerycznej nad mapą analogową jest możliwość dowolnego jej przetwarzania.

Pomimo tego, że mapy powinny być sporządzane w obowiązującym państwowym układzie współrzędnych prostokątnych płaskich PL-ETRF2000 [8], to nadal można jeszcze spotkać starsze dokumenty, w których zastosowano inne 
układy współrzędnych. Czasem są to układy lokalne, takie jak Sucha Góra czy Borowa Góra [9], a czasem dawne państwowe np. 1965.

System Geolisp został wyposażony w szereg poleceń służących do transformacji danych zawartych na mapie numerycznej do żądanego układu współrzędnych. Jak wynika z rysunku 4 , istnieje możliwość wyboru pomiędzy różnymi typami transformacji, począwszy od izometrycznej oraz konforemnej, a kończąc na transformacji między poszczególnymi układami współrzędnych.

Transformacje izometryczna oraz konforemna wymagają wskazania odpowiednich punktów dopasowania poprzez wybranie ich z rysunku lub też wczytanie z pliku. Punkty te można skontrolować pod względem dokładności dopasowania po uruchomieniu programu lub po wybraniu przycisku Kontrola.

\begin{tabular}{|l|l|l|l|}
\hline Transformacja & \multicolumn{1}{|c|}{ Kontrola } \\
Typ transformacji \\
OGEONET
\end{tabular}

Rys. 4. Okno dialogowe „Transformacja”

Fig. 4. Dialog box 'Transformation'

System Geolisp umożliwia również przeskalowanie obiektów z mapy podstawowej do dowolnej skali. Ponadto posiada on również szereg poleceń, które ułatwiają przygotowanie mapy do wydruku, m.in. wstawianie ramki mapy, opisów pozaramkowych, siatki krzyży oraz ustawienie odpowiednich kolorów i widoczności obiektów. 


\section{Obliczanie objętości zwałowisk}

Zagadnienia związane $\mathrm{z}$ tworzeniem numerycznego modelu terenu i złoża oraz $\mathrm{z}$ obliczaniem objętości to istotny element dokumentowania i planowania prac w kopalniach odkrywkowych. Możliwości technologiczne związane z pomiarem tego typu utworów skalnych są coraz większe, począwszy od nowoczesnych tachimetrów oraz odbiorników GPS, a skończywszy na dronach wyposażonych w skanery laserowe. Tego typu pomiary dostarczają bardzo wielu informacji o budowie danego nasypu, skarpy czy zwałowiska.

Są dwa sposoby uzyskania numerycznego modelu terenu w module Odkrywki. Pierwszy wymaga posiadania oprogramowania AutoCAD Civil 3D, drugi można stosować w dowolnym oprogramowaniu CAD, które obsługuje język oprogramowania LISP. Poniżej omówiono sposób drugi.

W pierwszej kolejności poleceniem CPKT wprowadzamy na mapę punkty $\mathrm{z}$ wykonanego pomiaru. Polecenie to tak przemieszcza opisy numerów i rzędnych punktów, aby na siebie nie nachodziły. Oprócz tego potrafi ono przetransformować współrzędne „w locie”.

Na rys. 5a przedstawiono okno dialogowe pokazujące listę dostępnych programów w menu MP-Sia, m.in. utworzenie siatki trójkątów i obliczanie objętości, wyrysowanie warstwic oraz dostosowanie ich opisu.

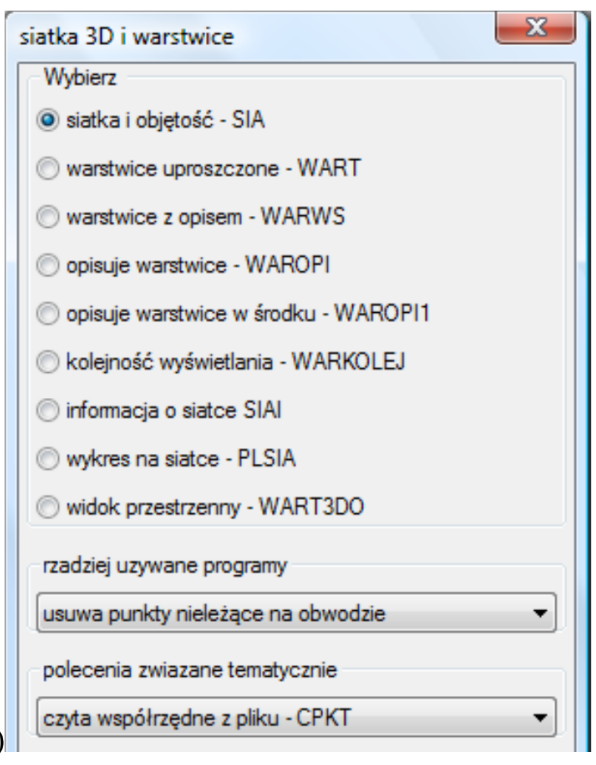

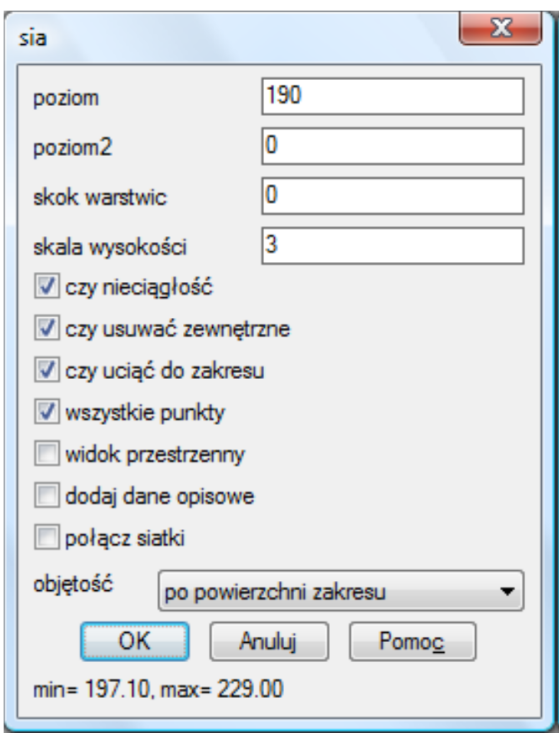

Rys. 5. Okno dialogowe „siatka 3D i warstwice” (a); Okno dialogowe „sia” (b)

Fig. 5. Dialog box '3D mesh and isolines' (a); Dialog box 'sia' (b) 
Polecenie SIA, które służy do wyznaczania objętości danej skarpy lub nasypu uruchamia kolejne okno dialogowe, jak na rysunku 5b. Program Zakres automatycznie rysuje obwiednię wskazanych punktów, którą można następnie ręcznie poprawić i która będzie granicą tworzonego modelu terenu. Podczas obliczeń uwzględniane są linie nieciągłości np. skarpy, potoki, jeziora - wcześniej trzeba wkreślić linie na odpowiednie warstwy rysunku.

Objętość siatki obliczana jest jako suma objętości graniastosłupów, których górna podstawa opiera się na siatce, a dolną podstawę stanowi, w zależności od wybranej opcji: dodatkowa powierzchnia trójkątów powstała w wyniku połączenia punktów obwiedni lub zdefiniowany poziom. Po zatwierdzeniu operacji pojawia się okno dialogowe zawierające informację o wyniku i zapisywany jest raport. Dostępna jest również opcja wygenerowania przestrzennego widoku obiektu przy pomocy polecenia WART3DO (rysunek 6).
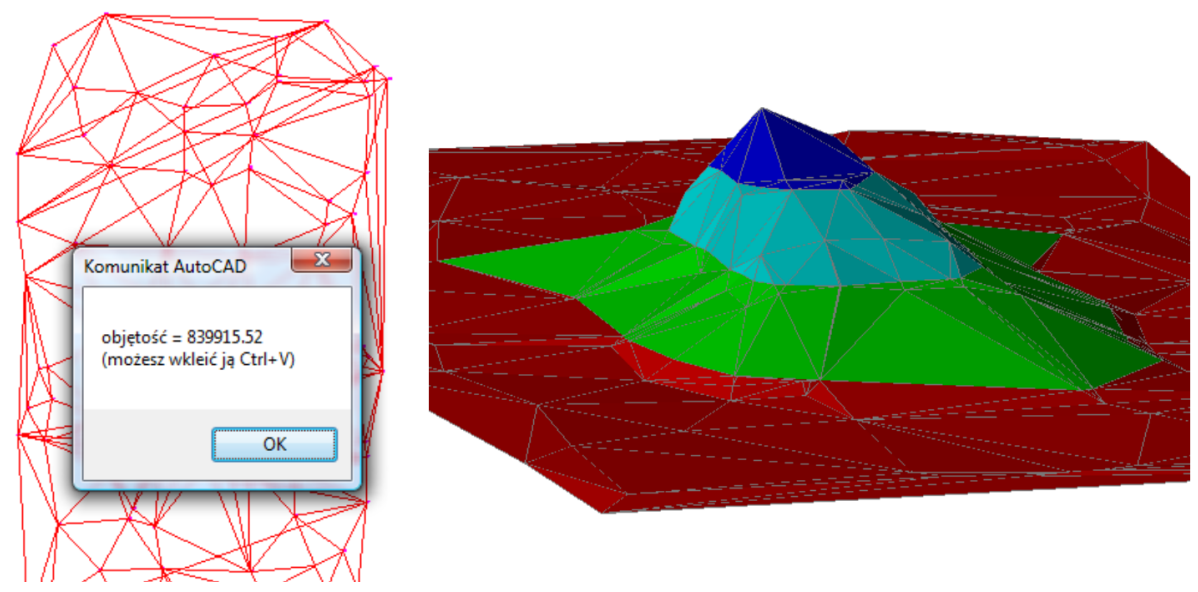

Rys. 6. Przykład obliczeń objętości i wizualizacji 3D zwałowiska

Fig. 6. Example of volume calculations and 3D visualization of embankment

\section{Tworzenie wykresów (profili i przekrojów)}

Program Geolisp zawiera także pakiet programów, które służą do automatycznego tworzenia wykresów. Dane potrzebne do stworzenia profilu lub przekroju mogą być zaczerpnięte z samego rysunku, jak i z przygotowanego wcześniej pliku tekstowego. Obie opcje muszą zawierać dane niezbędne do utworzenia wykresu. Aby stworzyć wykres, należy wybrać odpowiednią ikonę lub wpisać polecenie WYKRES. Następnie w oknie dialogowym należy ustalić źródło danych dla wykresu. Jeśli jest to plik wsadowy, to należy ustawić odpowiednią ścieżkę dostępu do tego pliku. Jeżeli zaś wykres ma być utworzony na podstawie danych z rysunku, należy wskazać na mapie linię przekroju. Po wybraniu opcji utworzenia przekroju z pliku tekstowego należy w oknie dialogowym ustawić 
odpowiednie założenia, tj. kolejność numerów punktów, współrzędnych sytuacyjnych i wysokościowych oraz które wysokości mają być czytane do sporządzenia wykresu, można na jednym wykresie przedstawić kilka linii np. skarpę, lustro wody i dno potoku.

W kolejnym oknie dialogowym (rys. 7b) można zmienić tytuł wykresu, ustawić jego skalę poziomą, pionową i obniżeń, poziom odniesienia i kilometraż początkowy. W przypadku, gdy plik źródłowy nie zawiera tych danych, są one automatycznie uzupełniane. Po zatwierdzeniu omawianych opcji program przechodzi do kolejnego okna dialogowego (rys. 7a), w którym można zaznaczyć, jakie informacje powinny znaleźć się na wykresie i wybrać miejsce jego wstawienia.
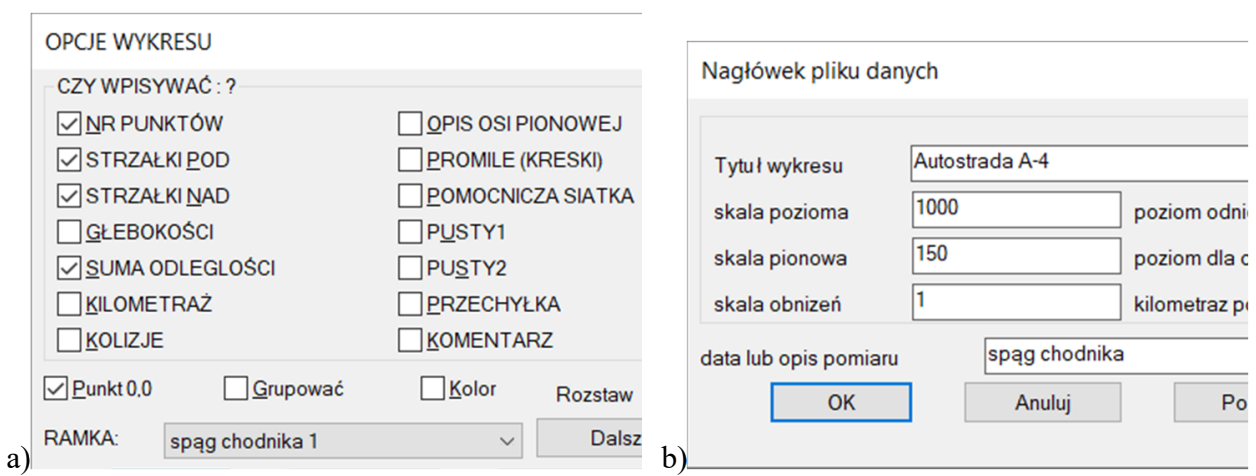

Rys. 7. Okno dialogowe „Opcje wykresu” (a); Okno „Nagłówek pliku danych” (b)

Fig. 7. Dialog box 'Graph option (a); Dialog box 'Title of data file' (b)

Istnieje również opcja zaprojektowania dodatkowej linii na utworzonym wcześniej wykresie np. projektowanego dna potoku - polecenie PROJ. W tym celu należy podać rzędną początku projektowanego odcinka i wpisać jego nachylenie. Aby dodać do wykresu zaprojektowaną linię, należy użyć polecenia ZAPPROJ. Do wykresu możemy dodać linię regresji liniowej, wielomianowej lub obliczonej metodą geostatystyczną.

Jeżeli wykres ma zostać wykonany na podstawie danych z rysunku, należy wybrać znajdującą się na rysunku polilinię 3D (lub wcześniej wrysować ją, łącząc punkty posiadające współrzędne X, Y i Z). Aby szybko utworzyć wykres na podstawie polilinii, należy wpisać polecenie WYK2 i wskazać odpowiednie dane. Program zapyta o miejsce wstawienia wykresu, należy je wskazać poprzez kliknięcie w pożądany punkt. 


\section{Tworzenie NMT na podstawie map numerycznych}

Numeryczny Model Terenu jest cyfrową, dyskretną reprezentacją wysokości topograficznej powierzchni terenu wraz z możliwością odtworzenia jej kształtu na określonym obszarze. NMT umożliwia m. in.: określenie wysokości punktu o znanych współrzędnych X i Y, zamodelowanie kształtu powierzchni terenu oraz określenie wielkości pochodnych od kształtu [10]. Jak podpowiada sama definicja, posiadanie NMT danego obszaru przynosi wiele korzyści. Na podstawie takiego modelu można w szybki sposób określić ukształtowanie terenu i wyznaczyć np. strefy zagrożone zalaniem, określić wysokości punktów i spadki zboczy, wyznaczyć objętości mas skalnych czy zbiorników wodnych oraz przeprowadzać wszelkie prace związane z projektowaniem na danym terenie. Aby wykonać taki model, niezbędne jest posiadanie danych dotyczących danego terenu. W przypadku, gdy na danym obszarze jest prowadzona mapa numeryczna, można wykorzystać informacje zawarte w obiektach takich, jak: bloki, punkty, linie nieciągłości czy warstwice lub inne pliki tekstowe. Na podstawie tych danych można utworzyć w programie AutoCAD Civil 3D powierzchnię trójkątów TIN, której właściwości i sposób wyświetlania poszczególnych jej komponentów wybiera sam użytkownik. Ponadto w przypadku, gdy danych jest zbyt dużo (może to spowodować nieczytelność obrazu lub trudności z przeliczeniem modelu), istnieje możliwość redukcji liczby punktów lub skrócenia krawędzi trójkątów. Program, na podstawie odpowiedniego wielomianu aproksymującego, wstawi dodatkowe punkty i uwzględni je podczas procesu wygładzania modelu.

Prowadzenie mapy numerycznej w systemie Geolisp pozwala na szybkie przetworzenie utworzonych obiektów, np. bloków miąższości i analizy chemicznej, punktów osnowy, kot wysokościowych czy otworów geologicznych na punkty, które stanowią podstawę do wykonania powierzchni TIN. Wówczas współrzędne sytuacyjne pokrywają się z punktem wstawienia bloku, natomiast trzecia współrzędna równa jest wartości danego atrybutu. Wstawienie do rysunku tak powstałych punktów pozwala na utworzenie powierzchni dowolnego parametru, np. spągu lub miąższości. Sposób wizualizacji takiej powierzchni można dopasować do własnych potrzeb, stosując np. kolorowy gradient, trójkąty lub izolinie. Na rys. 8 przedstawiono przykład wizualizacji powierzchni zasiarczenia złoża metodą zakresów.

W przypadku, gdy zajdzie potrzeba zmiany sposobu wizualizacji utworzonych powierzchni, należy wybrać polecenie OP (rys. 9). W programie tym można dowolnie operować stylami danej powierzchni, np. pokazać siatkę trójkątów, utworzyć warstwice czy mapę hipsometryczną. Można również dowolnie zmieniać sposób wizualizacji izolinii poprzez zmianę ich skoku czy koloru. Opis warstwic jest tak umieszczany, aby nie nachodził na inne obiekty rysunku. Program umożliwia przycięcie danej powierzchni do wybranej obwiedni. Istnieje możliwość uzyskania trójwymiarowej mapy terenu poprzez zrzutowanie punktów, bloków i innych obiektów na wybraną powierzchnię TIN. 


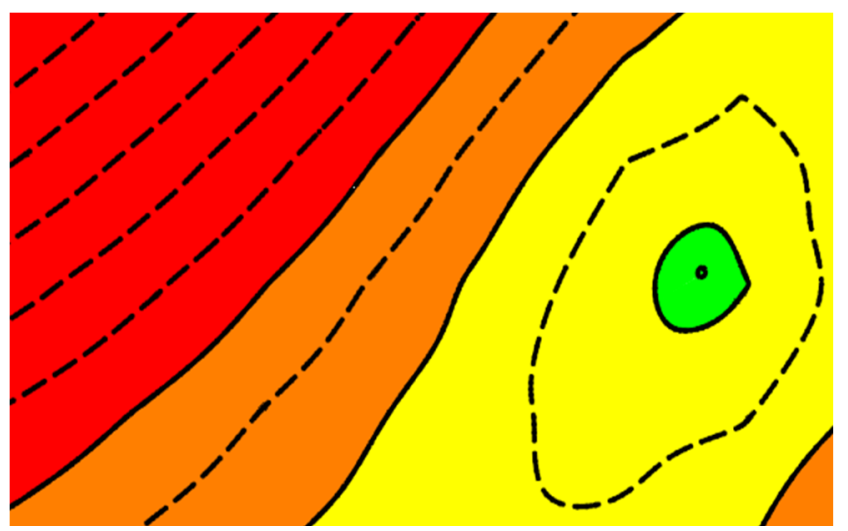

\begin{tabular}{|c|c|c|}
\hline \multicolumn{3}{|c|}{ Siarka } \\
\hline Od & Do & Kolor \\
\hline 0.7 & 0.8 & \\
\hline 0.8 & 1.2 & \\
\hline 1.2 & 1.6 \\
\hline 1.6 & 3.6 \\
\hline
\end{tabular}

Rys. 8. Wizualizacja powierzchni zasiarczenia złoża przy pomocy kolorowania

Fig. 8. Visualization of the sulfur surface using coloring option

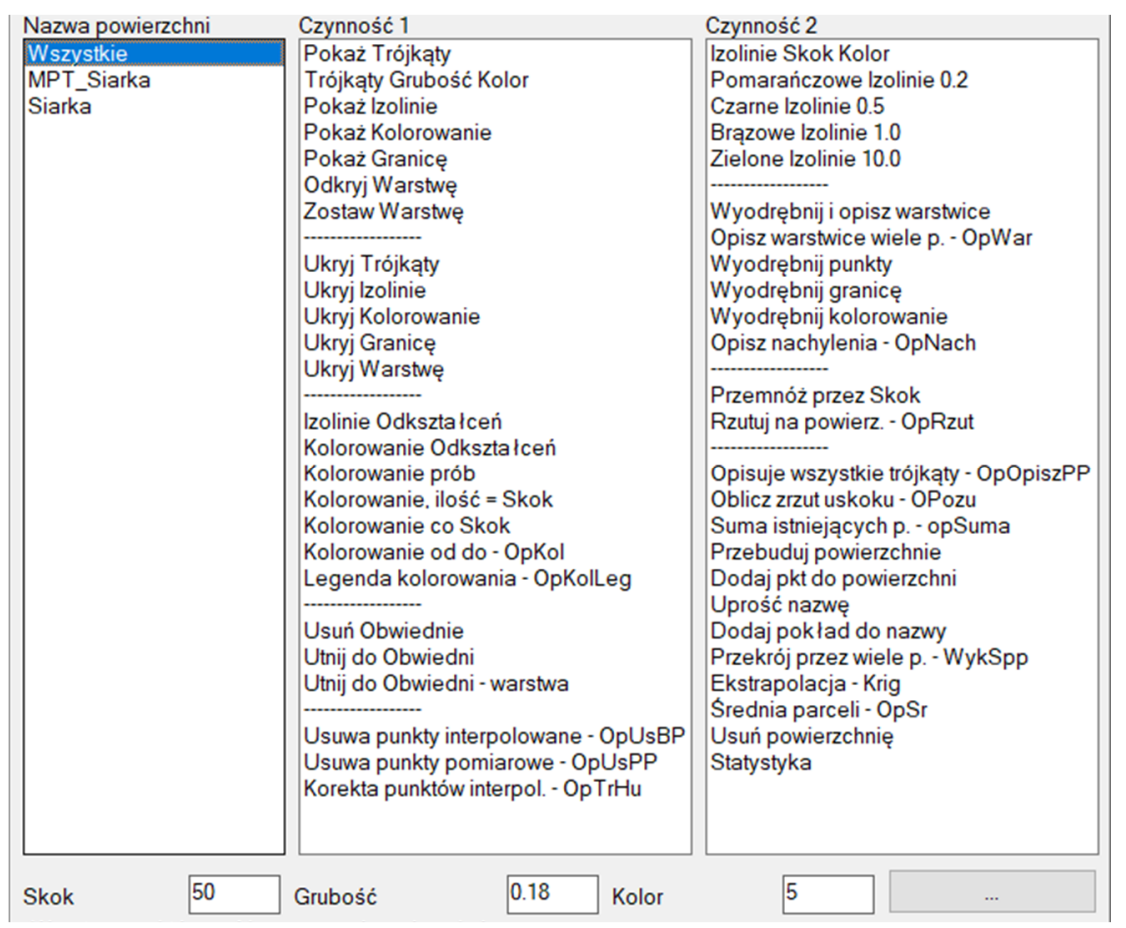

Rys. 9. Okno dialogowe „OP”

Fig. 9. Dialog box 'OP' 


\section{Topologia, generowanie map tematycznych}

Topologia jest zestawem geometrycznych relacji między poszczególnymi elementami rysunku. Określa ona, w jaki sposób linie, węzły i regiony łączą się i odnoszą do siebie. Pozwala na wykonanie przestrzennych analiz takich jak np. znalezienie najkrótszej drogi, znalezienie właścicieli działek, przez które przebiega planowany gazociąg itd. Topologia gwarantuje nam, że regiony np. parcele zasobowe nie nachodzą na siebie, ani nie ma między nimi pustych miejsc. W systemie Geolisp istnieje procedura ułatwiająca skontrolowanie topologicznej poprawności obiektów i stworzenie topologii. Najpierw sprawdzane są linie, następnie centroidy. W przypadku znalezienia błędów (niedociągnięć linii, krótkich odcinków, braku lub podwójnej centroidy) program zaznacza błędne miejsca i oczekuje ich poprawy. Program należy uruchamiać do momentu, gdy wszystkie błędy zostaną usunięte a topologia wykonana.

Geolisp daje możliwość sporządzania mapy tematycznej np. kolorując parcele zgodnie z ich kategorią rozpoznania. Stworzono narzędzie umożliwiające utworzenie raportu dla wskazanych na mapie parcel (zamkniętych polilinii utworzonych automatycznie na podstawie topologii). Na podstawie numerycznego modelu złoża program oblicza potrzebne dane np. tonaż złoża i przenosi je do arkusza kalkulacyjnego (rys. 10)

\begin{tabular}{|c|c|c|c|c|c|c|c|c|}
\hline$\angle$ & A & B & C & D & E & $\mathrm{F}$ & G & H \\
\hline 1 & Parcela & Pole & Miąższość & Postęp & Gęstość & Zasoby & Wydobycie & Upad \\
\hline 2 & $(\mathrm{nr})$ & [m2] & {$[\mathrm{m}]$} & {$[\mathrm{m} / \mathrm{d}]$} & {$[\mathrm{t} / \mathrm{m} 3]$} & [tys. t] & {$[\mathrm{t} / \mathrm{d}]$} & {$\left[{ }^{\circ}\right]$} \\
\hline 3 & C-1 & 269568 & 1.8 & 0.9 & 1.47 & 257.8 & 1215.8 & 15 \\
\hline 4 & $\mathrm{C}-2$ & 407866 & 1.8 & 0.9 & 1.45 & 288.3 & 1304.4 & 14 \\
\hline 5 & $C-3$ & 497017 & 2.2 & 0.8 & 1.42 & 369.6 & 1496.3 & 13 \\
\hline 6 & $C-4 a$ & 524928 & 2.5 & 0.8 & 1.41 & 331 & 1426.9 & 12 \\
\hline
\end{tabular}

Rys. 10. Fragment raportu parcel zasobowych

Fig. 10. Fragment of the resource parcel report

\section{Przekrój przez górotwór}

Istnieje procedura Karta-Otworu, która rysuje kartę otworu wiertnicze W programie zdefiniowano wszystkie normowane znaki umowne skał i surowców mineralnych. Kolejny program umożliwia wykonanie równocześnie przekroi przez wiele powierzchni TIN co pozwala wykonać przekrój przez górotwór. 


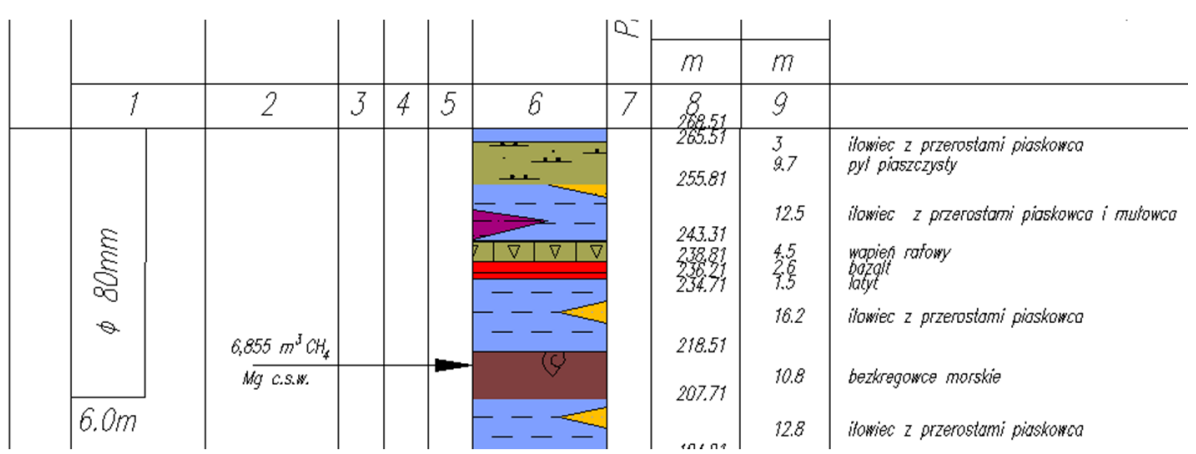

Rys. 11 Profil geologiczny

Fig. 11. Geological profile

\section{Podsumowanie i wnioski końcowe}

Przedstawiony w artykule opis modułu Odkrywki systemu Geolisp pokazuje jego przydatność przy tworzeniu dokumentacji kartograficznej dla zakładu górniczego wydobywającego kopaliny metodą odkrywkową. Zaprezentowane funkcje programu umożliwiają szybkie i precyzyjne tworzenie map górniczych oraz powierzchniowych dzięki bogatej bibliotece znaków i symboli umownych, utworzonych zgodnie z obowiązującymi aktami prawnymi oraz normami. Ponadto program wyposażony jest $\mathrm{w}$ wiele funkcji pozwalających na edycję powstałej dokumentacji np. przeskalowanie, zmiana układu współrzędnych, tworzenie map tematycznych. Autor programu stworzył także narzędzia, które umożliwiają automatyczne generowanie istotnych, z punktu widzenia projektowania dalszych prac górniczych, obiektów takich jak Numeryczny Model Terenu czy profile i przekroje. Należy podkreślić również, że program posiada bogatą bibliotekę poleceń, w której można szukać rozwiązań do zadań geodezyjnych oraz górniczych. Ponadto w pakiecie programu znajduje się wiele samouczków, które krok po kroku przeprowadzają użytkownika przez jego możliwości. System Geolisp, moduł Odkrywki to pakiet programów, które tworzą spójne i użyteczne narzędzie pracy w odkrywkowych zakładach górniczych. Większość poleceń dostępna jest w postaci bezpłatnego oprogramowania.

\section{Literatura}

[1] Kasztelewicz Z., Kozioł W.: Działalność górnictwa odkrywkowego w Polsce w okresie ostatnich 50 lat i perspektywa rozwoju na I połowę XXI wieku, Biuletyn AGH, nr 85, 2015, s. 8-15.

[2] Popczyk M.: Zarys górnictwa odkrywkowego, Wydawnictwo Politechniki Śląskiej, Gliwice, 2016.

[3] Ustawa Prawo geologiczne i górnicze z dnia 9 czerwca 2011 r. z późn. zm., Dz.U. $2011 \mathrm{nr} 163$ poz. 981. 
[4] Poniewiera M.: Zastosowanie oprogramowania Geolisp do budowy dynamicznego systemu informacji o przestrzeni górniczej. Syst. Wspomag. Inż. Prod. 2017 vol. 6 iss. 3, s. 213-222.

[5] PN-73/G-09016 Mapy górnicze. Umowne znaki wyrobisk odkrywkowych i zwałowisk.

[6] PN-73/G-09017 Mapy górnicze. Umowne znaki robót strzelniczych w górnictwie odkrywkowym.

[7] PN-73/G-09018 Mapy górnicze. Umowne znaki urządzeń i obiektów w górnictwie odkrywkowym.

[8] Rozporządzenie Rady Ministrów z dn. 15.10.2012 r. w sprawie Państwowego Systemu Odniesień Przestrzennych, Dz.U. 2012 poz. 1247.

[9] Maciaszek J.: System informacji o archiwalnych mapach i polach górniczych na potrzeby zagospodarowania przestrzennego, Wydawnictwo AGH, Kraków 2010, s. 98.

[10] Sitek Z.: Fotogrametria ogólna i inżynieryjna, Państwowe Przedsiębiorstwo Wydawnictw Kartograficznych im. Eugeniusza Romera, Warszawa-Wrocław 1991, s. 325 .

\section{APPLICATION OF GEOLISP COMPUTER PROGRAM TO CREATE CARTOGRAPHIC DOCUMENTATION OF OPENCAST MINING PLANT}

\section{S u m m a r y}

In this article was shown the 'Geolisp' system of numerical mining maps, taking into account an outcrop module. There have been discussed the subsequent functions of this module and a possibility of its use in creation of cartographic documentation in an opencast mining. There have been shown the ways of mining maps creation on the basis of the measuring data, in the first part of this article. The insertion methods of contractual signs, lines and crosshatchings were especially demonstrated here. Then it has been presented how to convert the created maps, inter alia: maps transformation between the coordinate systems, preparation of figures to printing and creation of derivative maps. In the article were discussed the main functions of 'Geolisp' program, namely: calculation of heaps volume, making of diagrams and profiles, and Triangular Irregular Networks based on created maps of mining excavations. These surfaces can be obtained from the contour lines or the altitude and situational coordinates of coal bed roof/floor juxtaposed in the text files. These surfaces enable to do a visualization of coal bed elements and plan the next mining works. It was also shown how to make a thematic map based on created topology. In this part of an article have been described the subsequent steps of parcels making and a control of their topology, and also the way of parcels report generating. It has been presented the module, which can be used to production preparation. The end of this article is focused on the practical examples of the use of cartographic documentation.

Keywords: opencast mining, numerical maps, mining maps, numerical deposit model, volume calculation

Przestano do redakcji: $24.08 .2017 \mathrm{r}$.

Przyjęto do druku: $15.12 .2017 \mathrm{r}$. 